\title{
O MODO DE VIDA DA MÃE E A SAÚDE INFANTIL
}

\author{
MATERNAL MODE OF LIVING AND CHILD HEALTH
}

EL MODO DE VIDA DE LA MADRE Y LA SALUD INFANTIL

Jane L.G. Dytz ${ }^{1}$

Semíramis M. M. Rocha ${ }^{2}$

RESUMO: O artigo investiga o modo de vida materno, que abrange tanto as condições materiais de existência como fatores ligados ao estilo de vida, para identificar até que ponto as políticas de saúde estão atendendo às necessidades das mães e crianças de baixa renda. Para tanto, utilizou-se entrevistas semi-estruturadas numa amostra de 17 mães residentes na periferia do Distrito Federal e com filhos menores de 6 anos. Seus relatos revelam um esquema de vida caracterizado por dificuldades financeiras, precárias condições de moradia, agravado por comportamento reprodutivo precoce, confinamento ao espaço doméstico e falta de lazer. Embora tenham acesso à atenção primária de saúde, deficiências importantes persistem em relação à qualidade dessa assistência. Para se conseguir um aprimoramento da saúde infantil, é preciso melhorar a situação da mãe.

PALAVRAS-CHAVE: condições socioeconômicas, estilo de vida materno, saúde infantil, qualidade de vida

ABSTRACT:In this article, maternal mode of living is investigated, examining both socioeconomic conditions and lifestyle factors, in order to identify to what extent health policies are tangibly meeting the needs of low income Brazilian mothers and children. Data are derived from unstructured interviews with 17 mothers with children under age 6 , residing in the Federal District, Brazil. Their stories reveal a life marked by economic difficulties and inadequate living conditions, aggravated by early reproductive behavior, confinement to the home and no leisure. Although they have access to primary health care, the quality is inadequate. Increased awareness to the mother's situation is necessary in order to improve the health of young children.

KEYWORDS: socioeconomic conditions, maternal lifestyle, child health, life story, quality of life

RESUMEN: El artículo investiga el modo de vida materno, que abarca tanto las condiciones materiales de existencia, como los factores relacionados al estilo de vida, para poder identificar hasta que punto las políticas de salud atienden las necesidades de niños y madres, cuya renta es poca o muy baja. Para ello se han utilizado entrevistas semiestructuradas en un muestreo de 17 madres de la periferia del Distrito Federal que tienen hijos con menos de 6 (seis) años. Sus relatos revelan un esquema de vida caracterizado por dificultades financieras y precarias condiciones de vivienda, que se ve agravado por un comportamiento reproductivo precoz y un confinamiento al espacio doméstico sin ningún tipo de ocio. Aunque tengan acceso a la atención primaria de salud, deficiencias importantes persisten respecto a la calidad de esa asistncia. Para conseguir un aprimoramiento de la salud infantil será preciso mejorar la situación de la madre.

PALABRAS CLAVE: condiciones socioeconómicas, modo de vida materno, salud infantil, calidad de vida

Recebido em 30/03/2002

Aprovado em 26/06/2002

\footnotetext{
${ }^{1}$ Professor Adjunto, Departamento de Enfermagem, Universidade de Brasilia.

2 Professor Titular, Escola de Enfermagem, Universidade de São Paulo, Ribeirão Preto - SP.
} 


\section{INTRODUCTION}

The relationship between childhood morbidity and economic factors, such as income and unemploment, is well documented (MORLEY; BICKNEL; WOODLAND, 1968, FIBGE, 1986, TRONCOSO, 1989). Besides these, there are other important variables that affect the health of young children, for in our society, they are cared for within their homes and depend on their mothers in order to survive (CALDWELL, 1981, MONTEIRO, 1990, BICEGO; BOERMA, 1993).

Ideas about child health have changed over the past 30 years, particularly in relation to the mother's role in determining health and disease. Initially, every childbearing woman was labeled as being of "risk" due to the possibility of the occurence of biological harm to both mother and child (LEAVELL; CLARK, 1965, SIMPSON, 1970). Little concern was given to socioeconomic factors, but this changed in the 70's and women from low income groups became the new target population (WHO, 1978, BACKETT; DAVIES; PETROSBARVAZIAN, 1984). More recently, the criteria used to define risk is no longer family income, since economic factors alone cannot predict the outcome of health and disease in certain social groups. The focus now is on the joint influence of psychological factors, socioeconomic conditions and life patterns (DE KADT; TASCA, 1993, PAHO, 1996).

This broader perspective refers to the general living conditions which encompass a variety of factors: income, job, food, housing, sanitary conditions, access to health care, maternal education - the latter defined in this study to characterize social status. From this outlook, a social group can be studied, on one hand, by its position in the economic structure (income and working conditons), and, on the other, by the type of social behavior it adopts. Together these two elements make up a certain way of living (PAIM, 1997).

The purpose of this paper is to investigate the mode of living oflow income mothers, examining socioeconomic conditions and lifestyle factors, in order to identify to what extent health policies are tangibly meeting the needs of mothers and children identified as the target population.

In this study, the concept of "mode of living" is decomposed analytically into two categories: a) living conditions which refer to those basic goods necessary for subsistence - such as housing, sanitation and other environmental factors - guaranteed directly by a person's income level and indirectly by public policies that assure the distribution of collective services among the population; b) lifestyle or a set of behaviors, habits and attitudes belonging to a certain individual or social group in which the voluntary component is greater, but also seen as determined by the type of education and socialization process a person grew up in.

The implementation of basic sanitary services and preventive measures, in the last 20 years, has had a positive, but limited, impact on the health of Brazilian mothers and children (SIMÕES; ORTIZ, 1988). Although there is improved access to health care, the population has endured several periods of intense and prolonged social and economic crisis, represented by economic recession and the rise of social inequalities (FIORI; KORNIS, 1994, OMETTO; FURTOSO; SILVA, 1995).
At the same time, Brazil experienced an unpredictable decrease in its population growth rate that has resulted in a lesser number of children per family (MONTEIRO; BENICIO; FREITAS, 1997). Presently, the country is undergoing a process of social and economic transformation in which traditional models are being substituted by a new economic order that is gradually transferring to nongovernmental agencies and the private sector the responsibility of providing for the population's basic needs, keeping public investments to a minimal level (WORLD BANK, 1995).

The main focus of public health programs has been and continues to be children from low income families, the majority of whom live in the periphery of large urban cities. Because the mothers are often uneducated, these children are considered more susceptible to acquiring easilypreventable diseases. Infant mortality rates provide some indications about the life patterns of this risk group, but do not display a real picture of their quality of life. That is why maternal mode of living is a fertile field to investigate the risk factors to which children are exposed, for it can contribute to a more in-depth dialogue about the health and well-being of children.

\section{MATERIALS AND METHOD}

STUDY DESIGN. A qualitative approach valuing the mother's perspective was chosen in order to help uncover aspects related to the health and well-being of children at the micro level, as well as expose wider social determinants of health and illness (MINAYO, 1993).

PARTICIPANTS AND STUDY SITE. The study was carried out in the area of the Federal District, which has a population of 2.3 million distributed in 18 urban communities located around the perimeter of Brasilia - capital of the country. Three of these urban areas were chosen as sites for the field work due to higher infant mortality rates (GDF, 1993). Using purposive sampling and the "saturation" criterion, 17 mothers were selected who matched the following profile: a) less than 8 years of formal education; b) minimum of two children under the age of $6 ; c$ ) client of the public health care system. The participants were contacted initially at their local health care center and, following their consent, interviewed in their homes at a preset date and time.

RESEARCH TECHNIQUES. The life story, a variation of the life history technique, was selected because it encourages free narratives. According to Denzin (1970), this technique allows the individual to describe spontaneously his or her life experiences, which can cover their entire life or a certain segment of it (topical life story), differing from the life history technique, in which the objective is not to reconstruct factual data, but capture the person's own interpretation about their personal history. In relation to the validity and quality of the narratives, these aspects are considered less relevant in this kind of research, for the aim is to understand, not dispute or test, the information supplied by the participants.

PROCEDURE. Data collection was carried out over 
a two-month period. A set of open-ended questions about experiences in childhood, motherhood and present life situation was used to initiate each interview, which lasted approximately 1 hour and was recorded. In addition to unstructured interviews, participant observation was used, which resulted in valuable field notes. After the interviews were completely transcripted, data was categorized and analyzed in order to identify similarities and discrepancies among the categories.

\section{RESULTS}

The findings of this study are presented in two parts: initially, a profile of the general socioeconomic conditions of the families; secondly, a description of certain aspects of the mothers' lifestyle related to child raising strategies, health practices and beliefs about motherhood. The findings, though exploratory, reveal the complex interrelation among factors that determine health and illness, pointing in the direction of a direct association between living conditions and health practices.

MARITAL STATUS. The group under study was composed of 17 mothers, aged 19 to 29 , the majority of whom have a common-law marriage. In general, the women got married at a young age, ranging from 16 to 20 , the mean age being 19 years. Two of the mothers are single and live at home with their parents, receiving no financial support from the father of their children. Of the married group, two are currently separated from their spouse.

NUMBER OF CHILDREN. There was a total of 40 children with ages ranging from 10 days of life to 11 years, all part of families made up, on average, of two or three siblings. Those aged 2 to 6 years were present in larger number ( 19 children), which added to the toddler group (12 to 23 months), made up of a total of 24 children, thus acounting for a little more than half of the total sample. The infants (less than 12 months of age) were present in lesser number ( 12 children) and the school-aged group (greater than 7 years of age) was limited to four children.

HOUSING, EMPLOYMENT AND INCOME. For the most part, the families interviewed live in small, improperly built houses. Many families crowd together in a single room that serves simultaneously as bedroom, kitchen and living room - such spaces being so divided by the few existing fumiture. Some of the families have property ownership, given by the government to low income communities, but most of them live in rented houses or loaned by relatives. About half of the families migrated, in recent years, from rural areas to the Federal District in pursuit of better socioeconomic conditons. The man is the main household provider, receiving his income from menial jobs - such as janitor, gardener, construction worker, - but more than half of them are presently unemployed, surviving on odd jobs. Only one of the mothers works outside the home on a regular basis since she is separated and has five children to support. The lack of day care centers for young children or other types of social support prevent the mothers from working outside the home. Even so, a few of them try to increase the family's income by doing occasional housecleaning jobs or taking care of other children in their own home. All of the families interviewed have a similar standard of living, characterized by low income, unemployment and difficulty in providing for theirbasicneeds. Consequently, they live in a state of permanent financial instability and vulnerability, surviving practically all month without any money at home.

BASIC SANITATION AND COMMUNITY DEVELOPMENT. The families live in communities which offer a minimal degree of sanitation and community development, such as sewage, piped water, eletricity and garbage collection. However, important deficiencies persist in terms of public safety, education, medical assistance and other areas related to quality of life. One mother expressed such a concern by reporting how childhood and adolescence are dangerous periods for kids who grow up in these peripheral communities for they are frequently exposed to street violence.

MATERNAL EDUCATION. The participants can be divided into two groups: a) those with more than four years of formal education; b) those with less than 4 years. Ten mothers belong to the first group, half of which have seven years of schooling, which means that they got very near completing the basic level. The second group is made up of seven mothers, all of which grew up in rural areas, including two mothers who can be considered illiterate for they completed only one year of formal schooling and are unable to read or write. The others claim to be literate, but expressed their frustration in not being able to carry out simple mathematical operations. According to their statements, this low level of education is the result of unfavorable socioeconomic conditions during their childhood, and, in some cases, to their parents' lack of belief in education for females. Education is seen by the young mothers as a means of social and professional ascent. Some of them hope to return to their studies in order to have a better quality of life in the future. Others are more concerned in guaranteeing an education for their children, such as enrollement in pre-school or grade school, which is a legitimate concern due to the shortage of public schools in their community.

HEALTH STATUS. The mothers reported few health problems, though a few already present stress-related disorders, such as hypertension, gastritis. As to the children, they are all vaccinated and demonstrate satisfactory development, but almost half of them (17 children) are undernourished and present recurring episodes of respiratory infections. The mothers tend to ignore specific signs and symptons, focusing instead on the general behavior of the child as a way of evaluating the child's well-being. Thus, half of the children were seen by their mothers as "healthy", whereas the remaining group was seen as "sickly", due to the fact that these children got ill more frequently and demanded greater attention from them. As to birth conditions, four children (10\%) were born with low birthweight (less than $2500 \mathrm{~g}$ ), including one born prematurely. The remaining children were bom with normal weight, none of which presented any complications during or following delivery. There was one case of infant death involving a 5-month-old boy who died of neurological complications. In regard to other illnesses, three 
children have convulsive disorders, varying in intensity and origin, all ofwhom are under medical treatment. Another girl, aged 4 years, has congenital cataracts in her right eye and inguinal hernia, both diagnosed by a doctor, but without any prospect of surgical intervention at the present time.

ACCESS TO HEALTH CARE. The participants are all frequent users of the public health system, none of whom have any type of health care plan or insurance. Only on exceptional occasions do they seek private medical services. For the most part, the mothers attend pre-natal assistance and take their children regularly to the health care center for medical examination, particularly in the first year of life. The mothers also have access to hospital assistance during childbirth, although they complain that this care is often minimal, hurried and impersonal. As to other medical services, the access is more difficult due to the shortage of health professionals and facilities. Despite their limited educational background, the mothers have legitimate concerns about acquiring sexually transmittable diseases or developing cancer, having expressed the desire to have access to preventive screening more frequently.

\section{MATERNAL LIFESTYLE}

From the distinct life stories, one feature stands out: independently of where they live, all of them basically share the same lifestyle pattern. The slight variations found can be credited to different types of upbringing, since half of the mothers sampled were born in rural areas, where they were exposed to a more rigid upbringing, whereas those who grew up in the Federal District had a more open and liberal education.

DAILY LIFE ROUTINE. Their day-to-day routine is spent, for the most part, carrying out domestic chores and taking care of the children. Motherhood is their primary role and they assume this task as part of their biological nature, reproducing the prevailing ideology about motherhood, as was evident in many of their statements. Almost all of the participants complained about their boring domestic routine and lack of leisure in their lives, the main reason for this being the lack of financial resources to be spent on this type of activity. Also, there are no parks or playgrounds in their communities where they can take their children to play.

CHILD RAISING. For the most part, the mother is the main person responsible for raising the children. Many of the women interviewed expressed how insecure they feel in carrying out this role, for they received no prior training. The grandmothers are often called upon, at difficult moments, to help them with the various domestic chores. None of the preschoolers attend school since their parents cannot afford to pay a private school and there are practically no public schools for this age group in the community. The mothers, in general, expressed that they want to give a more flexible upbringing to their children than the one they received. Many of them acknowledged the importance of play, but, at the same time, worry about disciplining and setting limits for their children. As to the father, his participation within the family is often seen as limited to that of breadwinner.
REPRODUCTIVE BEHAVIOR. The mothers share a pattern of adolescent pregnancy, most of which were unwanted and unplanned, together with a total lack of access to sexual education. Some of the mothers had children from different men, but, overall, the mothers tend to have monogamous relationships and attach great value to an affective bonding with their marriage partner. Among the participants, eight mothers had high risk pregnancies, which can be considered a relatively high percentage for the size of the sample. Although they received pre-natal assistance during pregnancy, their knowledge about childbirth was quite limited and caused them much suffering. As for contraception, only four mothers are presently using a birth control method, although all of them expressed their belief in family planning. The woman is still the one responsible for deciding which contraceptive method the couple will use, but there seems to be a growing awareness among the young mothers that this issue pertains not only to themselves.

HEALTH KNOWLEDGE AND PRACTICES. The mothers carry out a variety of health-related activities that range from hygienic and preventive measures to the treatment of certain common illnesses. Breastfeeding is a common practice. In general, they rely primarily on common sense to guide their health practices. This type of knowledge base has its worth and effectiveness in maintaining their children healthy, at least, at a minimal level, although the mothers don't always have a true notion of the gravity of the child's illness. One aspect about their capacity for self-care is their attentiveness to health problems among the members of the family, carefully observing behavioral changes in their children. At the sign of any trouble, they take appropriate action to solve the problem; the measures taken often depending on how the mother perceives the effectiveness of the various alternatives before her. In general, the mothers expressed their preference for medical assistance.

SOCIAL SUPPORT SYSTEM. The spouse is the mother's main support base and she values the family unit. Another source of support for the mother is her religion, which brings her comfort and hope. The aid from welfare institutions is practically inexistent, even for those families who are extremely poor.

DECISION MAKING AND AUTONOMY. Each mother lives isolated within her own private world, in which the range of options is very small and her decison-making capacity and sense of autonomy is restricted almost exclusively to domestic affairs. Many of them no longer feel satisfied with being housewives and mothers, desiring a broader range of opportunities for themselves - such as having an income of their own or going back to school in order to have a working career - but they lack the means to do so. The mothers have little opportunity to participate in more collective activities geared towards community development and women's rights.

\section{DISCUSSION}

As these young mothers struggle to form a family and raise their children, they tend to reproduce a certain 
lifestyle, which, together with the socieconomic conditions, influences their own health and that of their children. They carry an unjust and heavy load as they seek to manage their household in increasing scarce economic conditions. The lack of leisure and other forms of distraction contributes to a greater risk of acquiring stress-related diseases. Despite the sense of satisfaction that many of the mothers expressed about their situation, the fact remains that these women are tied to a rigid life scheme marked by confinement to the home, heavy domestic chores, isolation and a sense of powerlessness.

The mothers expressed their preference for medical assistance versus popular practices, thus indicating that much of the teachings disseminated by health programs have been incorporated by members of the target population. Public health policies implemented at the local level have resulted in a higher number of children vaccinated, greater access to preventive programs and even more extensive medical coverage. But even with these improvements, health care is still precarious for the vast majority of Brazil's population. By scrutinizing the life stories of these young women, it is possible to perceive that - although they have access to public transportation, primary health care, sanitation and other basic public services - their quality of life remains conditioned by their income level.

In order to enhance the health of children, it is necessary to improve the situation of the mother - her mental and physical well-being, her access to information. This type of support, unfortunately, is still very scarce. The health of women depends on general factors that go beyond those offered by the health sector, among which are work, education, income, including the eqüitable distribution of economic resources and political power (PEDERSON; O'NEIL; ROOTMAN, 1994).

No doubt this problem deserves greater attention from society in the sense of diminishing the gap between social policy and quality of life of mothers and children. This tasks belongs basically to the State, which can act in partnership with other sectors of society in order to stimulate community development, without forgoing its own responsibility in the elaboration and implementation of long-term social policy.

As to the health sector, what is needed is a more comprehensive health care model based on a concept which combines living conditions and people's well-being, and which embraces essentially an interdisciplinary approach to such issues. The local health care center - which, in many cases, is the only public facility available to people who live in low income urban communities - needs to rethink its role in society, particularly in terms of becoming an effective channel through which health promotion policy can be implemented and consolidated, hence contributing to diminish vulnerability and increase the quality of life of mothers and young children.

\section{REFERENCES}

BACKETT, E. M.; DAVIES, A. M.; PETROS-BARVAZIAN, A. The risk approach in health care: with special reference to maternal and child health, including family planning. Washington: WHO,1984.

BICEGO, G. T.; BOERMA, J. T. Maternal education and child survival: a comparative study of survey data from 17 countries. Soc. Sci. Med., v.36, n. 9, p.1207-27, 1993.
CALDWELL, J.C. La educación materna y su influencia en la mortalidad infantil. Foro Mundial de la Salud, v.2, n.1, p. 88-91, 1981.

DE KADT, E.; TASCA, E. Promovendo a eqüidade: um novo enfoque com base no setor da saúde. São Paulo: Hucitec,1993.

DENZIN, N. K. The research act: a theoretical introduction to sociological methods. New Jersey: Prentice Hall, 1970.

FIORI, J. L.; KORNIS, G. E. M. Além da queda: economia e política numa década enviesada. In: GUIMARÃES, R. M.; TAVARES, R. A. W., (Ed.) Saúde e sociedade no Brasil: anos 80. Rio de Janeiro: Relumé Dumará, 1994.

FUNDAÇÃO INSTITUTO BRASILEIRO DE GEOGRAFIA E ESTATISTICA. Perfil estatístico de crianças e mães no Brasil: aspectos sócio-econômicos da mortalidade infantil em áreas urbanas. Rio de Janeiro: FIBGE, 1986.

GOVERNO DO DISTRITO FEDERAL. Anuário estatístico do Distrito Federal. Brasilia:Codeplan, 1993.

LEAVELL, H. R.; CLARK, E. G. Preventive medicine for the doctor in his community. New York: McGraw-Hill, 1965.

MINAYO, M. C. S. O desafio do conhecimento: pesquisa qualitativa em saúde. 2. ed. São Paulo: Hucitec, 1993.

MONTEIRO, C.A.; BENICIO, M.H.D.; FREITAS, I. Changes in poverty related health indicators in Brazil: causes and impact on regional inequities. São Paulo, 1997. (Public Health Research Group/Research series 1).

MONTEIRO, M. F. G. O efeito da educação materna sobre o risco da mortalidade infantil. Rev.Bras. Estudos Popul., v. 7, n. 1, p.7485, 1990.

MORLEY, D.; BICKNELL, J.; WOODLAND, M. Factors influencing the growth and nutritional status of infants and young children in a Nigerian village. Trans. Royal Soc. Trop. Med. Hygiene, v.62, n. 2, p.164-95, 1968.

OMETTO, A. M. H.; FURTUOSO, M. C. O.; SILVA, M. V. Economia brasileira na década de oitenta e seus reflexos nas condições de vida da população. Revista Saúde Pública, v.29, n. 5, p. 40314, 1995.

PAIM, J.S. Abordagens teórico-conceituais em estudos de condições de vida e saúde: notas para reflexão e ação. In: BARATA, R.B, (Ed.). Condições de vida e situação de saúde. Rio de Janeiro:ABRASCO,1997.

PAN AMERICAN HEALTH ORGANIZATION. Health promotion: an anthology. Washington: PAHO, 1996. (Scientific Publication 557).

PEDERSON, A.; O'NEILL, M.; ROOTMAN, I. Health promotion in Canada: provincial, national and international perspectives. Toronto: Saunders, 1994.

SIMŌES, C. C. S.; ORTIZL.P. A mortalidade infantil no Brasilnos anos 80. In: CHADAD, J. P. Z.; CERVINI, R. (Ed.). Crise e infância no Brasil: o impacto das políticas de ajustamento econômico. São Paulo: Instituto de Pesquisas Econômicas da Faculdade de Economia e Administração da Universidade de São Paulo/ Unicef,1988. 
O modo de vida...

SIMPSON, J. An introduction to preventive medicine. London:William Heinemann Medical Books, 1970.

TRONCOSO, M. C. Componentes sociales, económicos y culturales del proceso salud-enfermidad en el primer año de vida del niño. In: LATTES, A. E.; FARREN, M.; MACDONALD, J., (Ed.). Salud, enfermedad y muerte de los niños en América
Latina. Ottawa:CLACSO/IDRC,1989.

WORLD HEALTH ORGANIZATION. Alma-Ata 1978: Primary health care. Geneva:WHO, 1978.

WORLD BANK. The organization, delivery and financing of health care in Brazil: an agenda for the 90's. Washington:World Bank,1995. 